Prepared in cooperation with the Arkansas Natural Resources Commission

\title{
Evaluation of Selected Model Constraints and Variables on Simulated Sustainable Yield from the Mississippi River Valley Alluvial Aquifer System in Arkansas
}

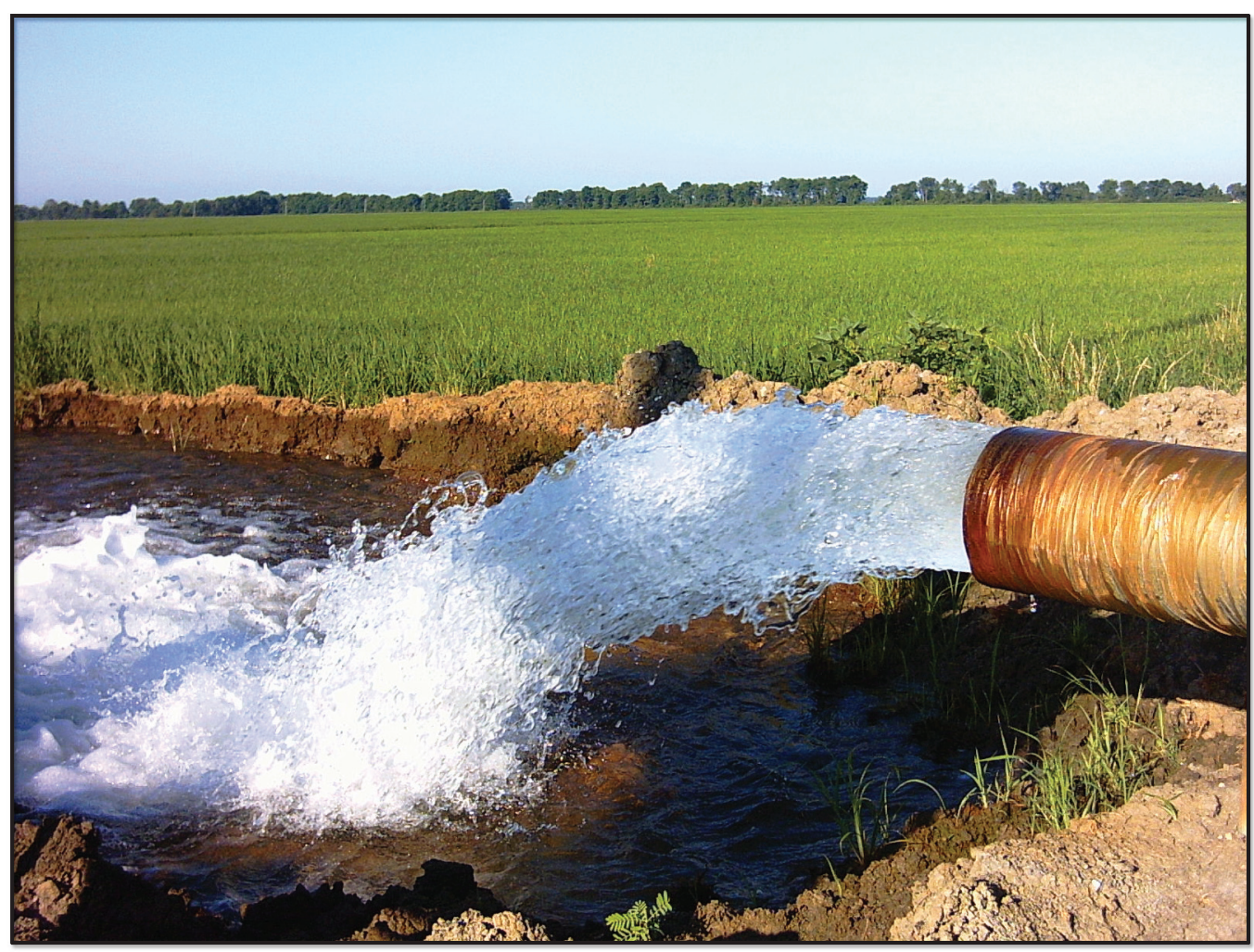

Scientific Investigations Report 2008-5138 
Cover photograph. Irrigation well in northeastern Arkansas (photograph by Ralf Montanus, U.S. Geological Survey, 2007). 


\section{Evaluation of Selected Model Constraints and Variables on Simulated Sustainable Yield from the Mississippi River Valley Alluvial Aquifer System in Arkansas}

By John B. Czarnecki

In cooperation with the Arkansas Natural Resources Commission

Scientific Investigations Report 2008-5138 


\section{U.S. Department of the Interior DIRK KEMPTHORNE, Secretary}

\section{U.S. Geological Survey \\ Mark D. Myers, Director}

\section{U.S. Geological Survey, Reston, Virginia: 2008}

For product and ordering information:

World Wide Web: http://www.usgs.gov/pubprod

Telephone: 1-888-ASK-USGS

For more information on the USGS--the Federal source for science about the Earth, its natural and living resources, natural hazards, and the environment:

World Wide Web: http://www.usgs.gov

Telephone: 1-888-ASK-USGS

Any use of trade, product, or firm names is for descriptive purposes only and does not imply endorsement by the U.S. Government.

Although this report is in the public domain, permission must be secured from the individual copyright owners to reproduce any copyrighted materials contained within this report.

Suggested citation:

Czarnecki, J.B., 2008, Evaluation of selected model constraints and variables on simulated sustainable yield from the Mississippi River Valley alluvial aquifer system in Arkansas: U.S. Geological Survey Scientific Investigations Report 2008-5138, 21 p. 


\section{Contents}

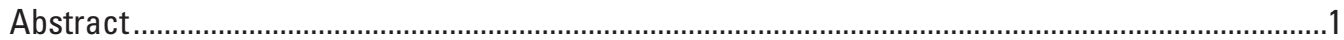

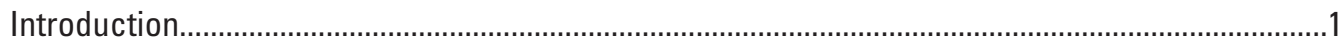

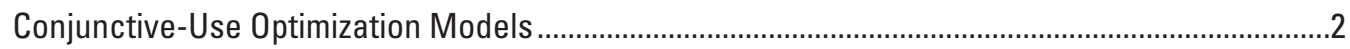

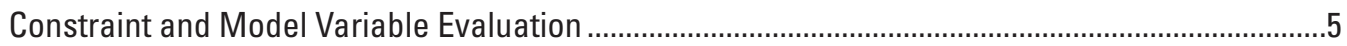

Upper Ground-Water Withdrawal Limit ..........................................................................

White River Streamflow Constraint Analysis ..........................................................................

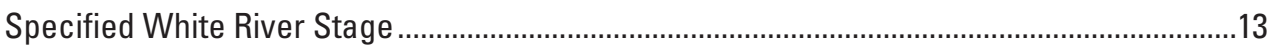

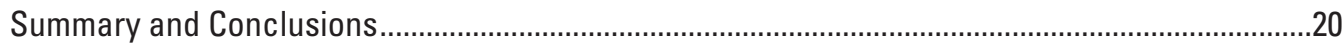

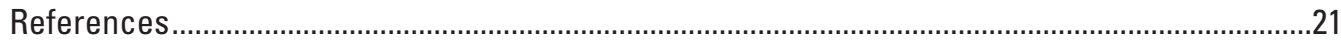

\section{Figures}

1-6. Maps showing:

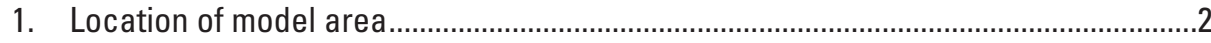

2. Optimized ground-water withdrawal rates and binding-constraint locations for scenario 1 (baseline), maximum withdrawal ratio of 1.0 ..........................................

3. Optimized ground-water withdrawal rates and binding-constraint locations for

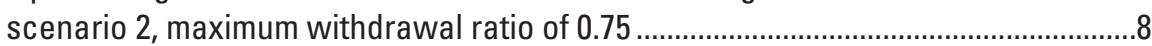

4. Optimized ground-water withdrawal rates and binding-constraint locations for

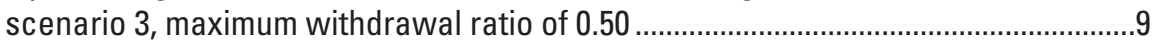

5. Optimized ground-water withdrawal rates and binding-constraint locations for scenario 4, maximum withdrawal ratio of 0.25

6. Change in ground-water withdrawal sustainable yield relative to the baseline scenario 1 compared to a maximum withdrawal ratio of 0.75 in scenario 2 .

7. Graph showing monthly average maximum, mean, median, and minimum streamflow from 1989 to 2005 at DeValls Bluff gage on the White River.

8-10. Photographs showing:

8. Areal view of Melinda Head Cut Structure relative to the White, Arkansas, and Mississippi Rivers

9. Melinda Head Cut Structure looking toward the northwest....................................15

10. Damage along the top of the Melinda Head Cut Structure, spring 2005 ..................15

11. Graph showing change in ground-water sustainable yield of the alluvial aquifer with stage of White River

12-14. Maps showing change in ground-water sustainable yield relative to the baseline scenario for a decline in the stage of the White River:

12. By 20 feet near its hypothetical confluence with the Arkansas River .17

13. By 30 feet near its hypothetical confluence with the Arkansas River ....................18

14. By 40 feet near its hypothetical confluence with the Arkansas River 


\section{Tables}

1. Rivers, streamflows, and streamflow constraints of the baseline scenario.

2. Summary of the effect of varying the upper ground-water withdrawal limit on ground-water sustainable yield

3. Monthly and annual streamflow statistics for U.S. Geological Survey streamflow gaging station 07077000, White River at DeValls Bluff, Arkansas, 1989 to 2005

4. Sumary of simulated streamflow components for the White River model cell at DeValls Bluff, Arkansas

5. Effect of lowering White River stage on ground-water sustainable yield of the alluvial aquifer.

\section{Conversion Factors and Datums}

\begin{tabular}{|c|c|c|}
\hline Multiply & By & To obtain \\
\hline \multicolumn{3}{|c|}{ Length } \\
\hline inch (in.) & 2.54 & centimeter (cm) \\
\hline foot $(\mathrm{ft})$ & 0.3048 & $\operatorname{meter}(\mathrm{m})$ \\
\hline foot per year (ft/yr) & 0.3048 & meter per year (m/yr) \\
\hline mile (mi) & 1.609 & kilometer (km) \\
\hline \multicolumn{3}{|c|}{ Area } \\
\hline square foot $\left(\mathrm{ft}^{2}\right)$ & 0.0929 & square meter $\left(\mathrm{m}^{2}\right)$ \\
\hline square mile $\left(\mathrm{mi}^{2}\right)$ & 2.590 & square kilometer $\left(\mathrm{km}^{2}\right)$ \\
\hline \multicolumn{3}{|c|}{ Volume } \\
\hline cubic foot $\left(\mathrm{ft}^{3}\right)$ & 7.481 & gallon (gal) \\
\hline cubic foot per day $\left(\mathrm{ft}^{3} / \mathrm{d}\right)$ & 0.0283 & cubic meter per day $\left(\mathrm{m}^{3} / \mathrm{d}\right)$ \\
\hline \multicolumn{3}{|c|}{ Flow rate } \\
\hline million cubic feet per day $\left(\mathrm{ft}^{3} / \mathrm{d}\right)$ & 7.481 & million gallons per day (Mgal/d) \\
\hline
\end{tabular}

Altitude, as used in this report, refers to distance above the vertical datum, and is referenced to the National Geodetic Vertical Datum of 1929 (NGVD of 1929).

Latitude and longitude are referenced to the North American Datum of 1983 (NAD of 1983). 


\title{
Evaluation of Selected Model Constraints and Variables on Simulated Sustainable Yield from the Mississippi River Valley Alluvial Aquifer System in Arkansas
}

\author{
By John B. Czarnecki
}

\section{Abstract}

An existing conjunctive use optimization model of the Mississippi River Valley alluvial aquifer was used to evaluate the effect of selected constraints and model variables on ground-water sustainable yield. Modifications to the optimization model were made to evaluate the effects of varying (1) the upper limit of ground-water withdrawal rates, (2) the streamflow constraint associated with the White River, and (3) the specified stage of the White River. Upper limits of ground-water withdrawal rates were reduced to 75,50 , and 25 percent of the 1997 ground-water withdrawal rates. As the upper limit is reduced, the spatial distribution of sustainable pumping increases, although the total sustainable pumping from the entire model area decreases. In addition, the number of binding constraint points decreases. In a separate analysis, the streamflow constraint associated with the White River was optimized, resulting in an estimate of the maximum sustainable streamflow at DeValls Bluff, Arkansas, the site of potential surface-water withdrawals from the White River for the Grand Prairie Area Demonstration Project. The maximum sustainable streamflow, however, is less than the amount of streamflow allocated in the spring during the paddlefish spawning period. Finally, decreasing the specified stage of the White River was done to evaluate a hypothetical river stage that might result if the White River were to breach the Melinda Head Cut Structure, one of several manmade diversions that prevents the White River from permanently joining the Arkansas River. A reduction in the stage of the White River causes reductions in the sustainable yield of ground water.

\section{Introduction}

The Mississippi River Valley alluvial aquifer (hereafter referred to as the alluvial aquifer) is a water-bearing assemblage of gravels and sands that underlies most of eastern Arkansas and several adjacent States. Ground-water withdrawals have caused cones of depression to develop in the aquifer's water-level surface, some as much as 100 feet (ft) deep. Long-term water-level measurements in the alluvial aquifer show an average annual decline of 1 foot per year in some areas (Schrader, 2001). The expansion of the cones of depression and the consistent water-level declines indicate that ground-water withdrawals are occurring at a rate that is greater than the sustainable yield of the aquifer. Rivers, such as the Arkansas, White, St. Francis, and Mississippi Rivers, are in hydraulic connection with the alluvial aquifer. Recharge to the alluvial aquifer from these rivers becomes induced as groundwater level declines.

For many years, the Arkansas Natural Resources Commission (ANRC) and other agencies have worked with the U.S. Geological Survey (USGS) in the development of ground-water flow models to be used as management tools to determine the sustainability of the water resource and the feasibility of various water-management scenarios. In a management scenario, specification of withdrawal locations from wells and from points along rivers (all with fixed withdrawal limits) are made, as are constraints with respect to water levels or streamflows that must be maintained for a feasible outcome. Ground-water flow models of two areas of the alluvial aquifer (north alluvial model and south alluvial model — divided by the Arkansas River) were developed for eastern Arkansas and parts of northern Louisiana, southeastern Missouri, and adjacent States (Reed, 2003; Stanton and Clark, 2003). The flow models showed that continued ground-water withdrawals at 1997 rates for the alluvial aquifer could not be sustained indefinitely without causing water levels to decline below half of the original saturated thickness of the alluvial aquifer, a water level that is consistent with Critical GroundWater Area designation by the ANRC for certain counties in eastern Arkansas. To develop estimates of withdrawal rates that could be sustained relative to the constraints of critical ground-water area designation, conjunctive-use (ground water and surface water) optimization modeling (hereafter referred to as optimization modeling) was applied to the flow models (fig. 1) (Czarnecki and others, 2003a, 2003b). Optimization modeling was used to calculate the maximum sustainable yield from wells and rivers, while maintaining simulated water levels and streamflows at or above minimum specified limits. However, those analyses represented only a few of the possible 


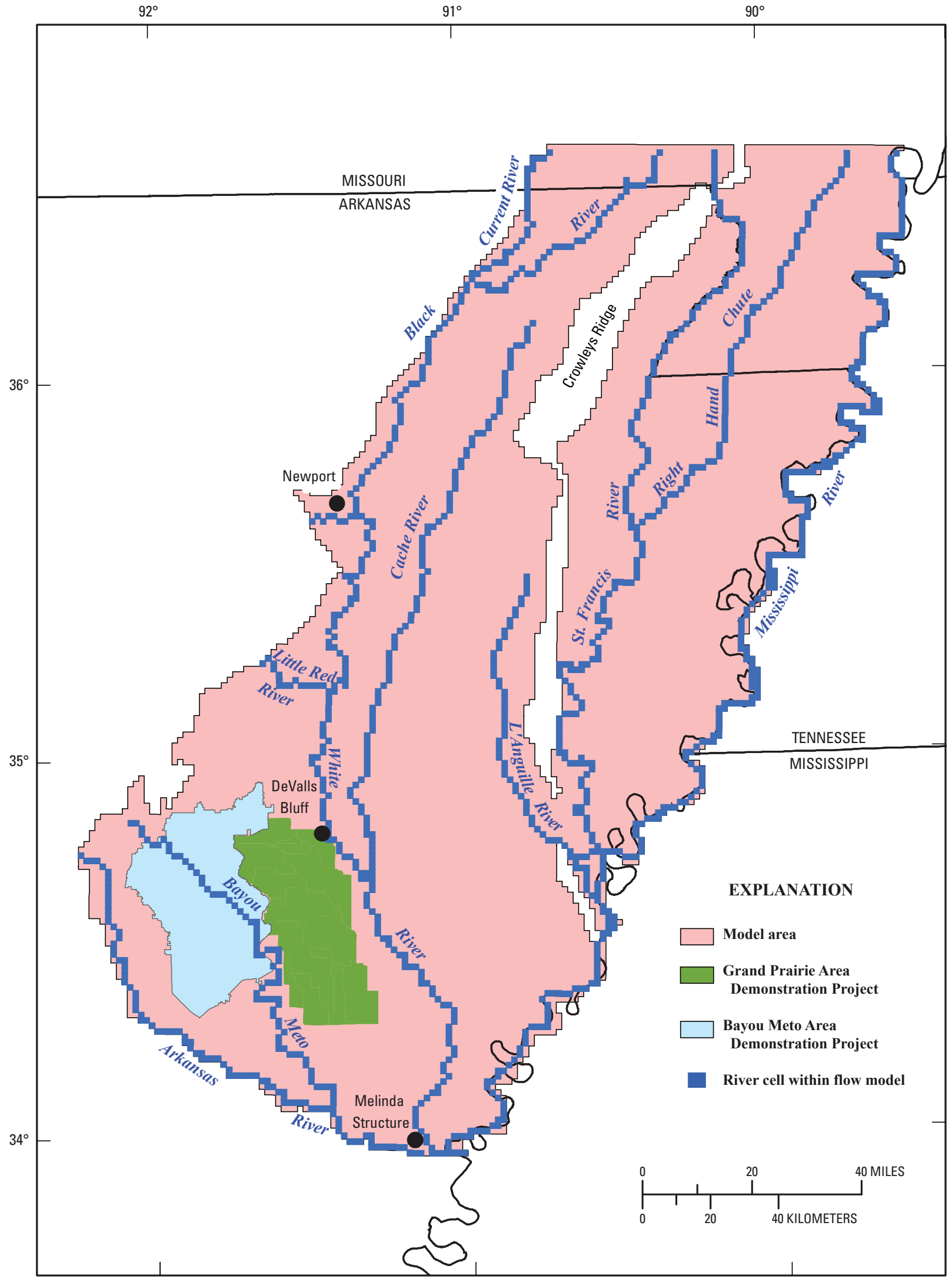

Base from U.S. Census Tiger/line files, 2008

Figure 1. Location of model area. 
management scenarios that might be considered for managing the ground- and surface-water resources. For example, if river discharges are maintained without additional surface-water withdrawals, a larger sustainable yield of ground water should be realized. Additional optimization modeling was done by the USGS in cooperation with the ANRC to simulate selected management scenarios for the alluvial aquifer.

The purpose of this report is to evaluate selected model constraints and variables on sustainable yield from the Mississippi River Valley alluvial aquifer. The effect of different scenarios on estimates of sustainable yield in three additional applications of the north alluvial model of Czarnecki and others (2003a) were evaluated for the following conditions: (1) varying upper limits of ground-water pumping in the modeled area so that at least some sustainable pumping can occur at all model cells representing wells that were pumping during 1997, (2) varying streamflow constraints for the White River so that minimum flow rates are at or greater than specified amounts corresponding to average spring floods and habitat requirements for select aquatic species, and (3) varying the specified stage in the lower White River so that stage corresponds to that which might result from the breaching and failure of the Melinda Head Cut Structure (Melinda Structure), and assessing the effects of that change in river stage on optimized ground-water pumping.

\section{Conjunctive-Use Optimization Models}

This section provides a brief summary of the optimization model previously developed for the north alluvial aquifer; a complete description of the model is provided in Czarnecki and others (2003a). Integral to the optimization models is the concept of sustainable yield, which is the rate at which water can be withdrawn indefinitely from ground- and surface-water sources without violating specified constraints. This rate is calculated through the use of the conjunctive-use models. The models consist of an objective function, decision variables, and constraints. Specifically, the objective function is to maximize the total rate of withdrawal from ground- and surfacewater sources. The decision variables are the withdrawal rates calculated at managed well sites and river-diversion sites. Constraints consist of water levels and streamflow rates that are specified at locations within the model domain. The sustainable yield from rivers represents a potential source of water that could supplement ground water. There were 9,979 managed well sites in the north alluvial model and 1,165 riverwithdrawal sites (Czarnecki, 2003a). Each well site in the model is a model cell representing an area of one-square mile that contains at least one well that was pumped in 1997. Each river-withdrawal site in the model is a model cell representing an area of one-square mile that may or may not have had surface water pumped from it in 2000.

In this report, the optimization models were formulated as linear programming problems with the objective of maxi- mizing water production from wells and from streams subject to: (1) maintaining ground-water levels at or above specified levels, (2) maintaining streamflow at or above minimum specified rates, and (3) limiting ground-water withdrawals to the rate pumped in 1997. Steady-state conditions were selected (rather than transient conditions) because the maximized withdrawals are intended to represent sustainable yield of the system (a rate that can be maintained indefinitely). Decision variables (a term used in optimization modeling to identify variables that can be part of a management scheme) are the withdrawal rates at 9,979 model cells corresponding to well locations and at 1,165 river cells.

The objective of the optimization model is to maximize water production from ground- and surface-water sources. The objective function of the optimization model has the form:

$$
\operatorname{maximize} \mathrm{z}=\sum q_{\text {well }}+\sum q_{\text {river }}
$$

where

$$
\begin{aligned}
& \mathrm{z} \quad \begin{array}{l}
\text { is the total managed water withdrawal, in } \\
\text { cubic feet per day; }
\end{array} \\
& \sum q_{\text {well }} \text { is the sum of ground-water withdrawal rates } \\
& \text { from all managed wells, in cubic feet per } \\
& \text { day; and }
\end{aligned}
$$

Equation 1 is computed such that the following constraints are maintained:

$$
h_{c} \geq h_{\text {minimum }}
$$

where

$$
\begin{array}{ll}
h_{c} & \text { is the hydraulic head (water-level altitude) at } \\
h_{\text {minimum }} & \text { constraint location c, in feet; and } \\
& \text { is the water-level altitude at half the thick- } \\
\text { ness of the aquifer, in feet. }
\end{array}
$$

To accommodate the ANRC Critical Ground-Water Area criterion that water levels within the alluvial aquifer should remain above half the original saturated thickness of the aquifer, hydraulic-head constraints were specified at 2,804 model cells. The range in values of half the original saturated thickness of the aquifer specified in the model is 6 to $96 \mathrm{ft}$. For a few cells where the original saturated thickness of the aquifer is less than $60 \mathrm{ft}$ but at least $30 \mathrm{ft}$, the hydraulic-head constraint was specified as $30 \mathrm{ft}$, a minimum thickness considered necessary for the aquifer to remain viable in those areas. The spatial distribution of constraint points represents approximately every fifth model cell. If water levels were to drop everywhere to the level of the head constraint, then the resulting saturated thickness of the alluvial aquifer would range from 30 to $100 \mathrm{ft}$.

Streamflow is regulated in Arkansas by ANRC for purposes of maintaining water quality, navigation, and species 
habitat. Streamflow constraints for several rivers specified in the optimization model were provided by ANRC (Steve Loop, Arkansas Natural Resources Commission, written commun., 2001). Streamflow constraints are specified as the minimum amount of flow required at individual river cells. In this model, a streamflow constraint is applied uniformly along an entire stream reach. The equation governing the relation between streamflow constraints and flow into and out of a stream is

$$
\begin{aligned}
& q_{\text {head }}^{R}+\sum q_{\text {overland }}^{R}+\sum q_{\text {groundwater }}^{R}-\sum q_{\text {diversions }}^{R}- \\
& \sum q_{\text {river }}^{R} \geq q_{\text {minimum }}^{R}
\end{aligned}
$$

$$
\begin{aligned}
& \text { where } \\
& q_{\text {head }}^{R} \quad \text { is the flow rate into the head of stream reach } \\
& \sum q_{\text {overland }}^{R} \\
& \sum q_{\text {groundwater }}^{R} \\
& \sum q_{\text {diversions }}^{R} \\
& \sum q_{\text {river }}^{R} \\
& q_{\text {minimum }}^{R} \\
& \mathrm{R} \text {, in cubic feet per day; } \\
& \text { is the sum of all overland and tributary flow } \\
& \text { to stream reach } \mathrm{R} \text {, in cubic feet per day; } \\
& \text { is the sum of all ground-water flow to or } \\
& \text { from stream reach } \mathrm{R} \text {, in cubic feet per day; } \\
& \text { is the sum of all surface-water diversions } \\
& \text { from stream reach } \mathrm{R} \text {, in cubic feet per day; } \\
& \text { is the sum of all potential withdrawals, not }
\end{aligned}
$$

The proximity of managed wells to model flow boundaries was taken into account to properly formulate the management objective. If no limit is imposed on the potential amount of water that can be pumped at each managed well, then those wells nearest model sources of water, such as rivers or general head boundaries, will be the first to be supplied water, thus capturing flow that would otherwise reach wells further from the sources.

Test simulations using 1997 withdrawal rates applied to steady-state conditions yielded large areas with dry cells in the flow model. Therefore, ground-water demand limits were specified at each cell as a multiple of the amount pumped in 1997, such that

$$
0 \leq q_{\text {well }_{i}} \leq M q_{\text {well }_{1997}}
$$

where

$$
\begin{array}{ll}
q_{\text {well }_{i}} & \text { is the optimal ground-water withdrawal for } \\
& \text { well } i, \text { in cubic feet per day; } \\
M & \text { is a multiplier between } 1 \text { and } 2 ; \text { and } \\
q_{\text {well }_{1997}} & \begin{array}{l}
\text { is the total amount withdrawn in } 1997 \text { from } \\
\text { all wells, in cubic feet per day. }
\end{array}
\end{array}
$$

No limits were imposed on optimized withdrawals from rivers such that the range in optimal withdrawal was between zero and the maximum amount of water available (that is, the withdrawal rate from rivers was the amount over and above the required minimum flow rate set by the constraint value) at a given point in a given river. This specification permitted analysis of where water could be produced and the maximum amount available. Withdrawals were allowed at all river cells. Because each withdrawal amount is optimized, it is dependent on all of the model constraints and conditions, not just those in the immediate vicinity of the withdrawal.

For optimization, 9,979 one-square mile cells were used to represent pumping from 35,043 wells in 1997. Each cell was specified as a managed well (that is, a decision variable) within MODMAN (Greenwald, 1998). In 1997, the annual pumping rate for all wells was 635.6 million cubic feet per day $\left(\mathrm{Mft}^{3} / \mathrm{d}\right)$. Note that in the north alluvial model (Reed, 2003), dry cells occurred causing pumping wells at the dry cells to become inactive, reducing total pumping to $631 \mathrm{Mft}^{3} / \mathrm{d}$. For the sustainable-yield analysis, the optimized rate at each of the 9,979 cells was allowed to vary between a rate of zero to a maximum rate equal to a multiple between 1 and 2 to that which was pumped in 1997. An upper limit was specified because no limit on pumping led to unrealistic optimal withdrawal rates from wells adjacent to rivers.

To allow for both optimal conjunctive use of surface water and ground water within the optimization model, 11 rivers were specified (table 1). Flow into the uppermost cell of each river is based on mean-annual flow at a USGS streamflow gage for the period of record, which includes high-, moderate-, and low-flow conditions, and the proportion of the drainage area that would drain into the uppermost cell. Overland flow is an estimate of water entering the river from tributaries and surface runoff within the area of the drainage. Overland flow is an approximate value derived by delineating the drainage subbasins between gaged reaches of the model streams, taking the difference in mean-annual streamflow from the gages, and uniformly distributing that difference to each of the model cells for each specific reach. Overland flows less the amount of water diverted or withdrawn during 2000 and planned diversions from Bayou Meto and Grand Prairie irrigation projects are listed in table 1. Planned diversions are $63,339,248 \mathrm{ft}^{3} / \mathrm{d}$ for the Bayou Meto project area and $55,078,367 \mathrm{ft}^{3} / \mathrm{d}$ for the Grand Prairie project area. Where a streamflow constraint was not provided by ANRC, an arbitrary value of zero was specified (Current and Right Hand Chute) except in the case of the Mississippi River where a value of 50 billion $\mathrm{ft}^{3} / \mathrm{d}$ was specified. If a value of zero was specified, then a stream could be pumped dry; however, this condition occurred only in Right Hand Chute. 
Table 1. Rivers, streamflows, and streamflow constraints of the baseline scenario (modified from Czarnecki and others, 2003a).

$\left[\mathrm{ft}^{3} / \mathrm{d}\right.$, cubic foot per day]

\begin{tabular}{lcrrr}
\hline \multicolumn{1}{c}{ River name } & $\begin{array}{c}\text { Number of } \\
\text { model cells }\end{array}$ & $\begin{array}{c}\text { Flow into uppermost } \\
\text { river cell of model } \\
\left(\mathbf{f t}^{3} / \mathbf{d}\right)\end{array}$ & $\begin{array}{c}\text { Overland flow less } \\
\text { surface withdrawals } \\
\text { per river } \\
\left(\mathbf{f t}^{3} / \mathbf{d}\right)\end{array}$ & $\begin{array}{c}\text { Minimum } \\
\text { flow constraint } \\
\left(\mathbf{f t}^{3} / \mathbf{d}\right)\end{array}$ \\
\hline Arkansas & 97 & $4,903,200,000$ & $87,338,294$ & $100,224,000^{1}$ \\
Bayou Meto & 77 & $17,020,800$ & $69,289,254$ & $605,000^{1}$ \\
Black & 88 & $148,996,800$ & $960,301,031$ & $27,302,400^{1}$ \\
Cache & 105 & $50,328,000$ & $207,634,689$ & $950,400^{1}$ \\
Current & 31 & $280,886,400$ & $61,386,926$ & $0^{2}$ \\
L'Anguille & 54 & $21,556,800$ & $107,769,192$ & $3,974,400^{1}$ \\
Little Red & 15 & $247,017,600$ & $19,501,549$ & $0^{1}$ \\
Mississippi & 305 & $50,185,440,000$ & $911,455,120$ & $50,000,000,000^{2}$ \\
Right Hand Chute & 74 & $244,944,000$ & $44,997,010$ & $0^{2}$ \\
St. Francis & 169 & $231,552,000$ & $1,884,825,939$ & $7,257,600^{1}$ \\
White & 150 & $1,248,480,000$ & $1,807,462,700$ & $665,000,000^{1}$ \\
Total & 1,165 & $57,579,422,400$ & $6,161,961,704^{3}$ & $50,805,313,800$ \\
\hline
\end{tabular}

${ }^{1}$ Provided by Arkansas Natural Resources Commission.

${ }^{2}$ Arbitrarily selected by U.S. Geological Survey.

${ }^{3}$ Summation assumes that overland flow less surface withdrawals is applied at river cell, and includes planned diversons for Bayou Meto and Grand Prairie irrigation projects.

\section{Constraint and Model Variable Evaluation}

Several water-management scenarios involving different constraint and model variable specifications were evaluated using the optimization model. As implied in the previous section, the sustainable yield calculated by the optimization model is dependent on the defined upper limits (constraints) on withdrawal rates at wells and rivers that are specified in the model; consequently, sustainable yield is likely to change as the values of the specified withdrawal rates are varied. Rates of sustainable yield also depend on the values of ground-water levels specified in the optimization model; if the specified values are relaxed (that is, ground-water levels are allowed to be drawn down further), then the sustainable yield of the aquifer should increase. This section describes management scenarios from optimization-model runs in which the specified values of upper ground-water withdrawal limits, White River streamflow constraints, and river stage in the White River were varied in the model.

\section{Upper Ground-Water Withdrawal Limit}

Upper ground-water withdrawal limits were varied for each model cell in the model area to evaluate the distribution of sustainable withdrawal locations that would result, as well as the location of binding water-level constraint points. They are called binding constraints because they prevent additional pumping and thus bind the solution (Ahlfeld and Mulligan, 2000, p. 70). The baseline scenario for the ground-water withdrawal limit evaluation is scenario 4 from Czarnecki (2003a), which uses an upper limit of 100 percent of the 1997 groundwater withdrawal rate at each model cell. Surface-water withdrawals are fixed at 2000 rates at select points, and no additional withdrawals are permitted. In addition, no withdrawals from either the Bayou Meto or Grand Prairie project areas that would remove water from the Arkansas and White Rivers, respectively, are specified. Water-level constraints are relaxed to have at least $30 \mathrm{ft}$ of saturated aquifer thickness.

The upper ground-water withdrawal limit subsequently was specified as 100, 75, 50, and 25 percent of the 1997 rate (withdrawal ratios of $1.0,0.75,0.50$, and 0.25 , respectively). As the upper limit is reduced, the distribution of cells with sustainable yields greater than zero increases, and the number of binding constraint points decreases because water-level altitudes are not lowered as much when maximum pumping rates are reduced. Table 2 summarizes the results of varying 
Table 2. Summary of the effect of varying the upper ground-water withdrawal limit on ground-water sustainable yield.

\begin{tabular}{|c|c|c|c|c|c|c|}
\hline Scenario & $\begin{array}{c}\text { Ratio of upper } \\
\text { ground-water } \\
\text { withdrawal } \\
\text { limit to } 1997 \\
\text { withdrawal } \\
\text { rate }\end{array}$ & $\begin{array}{c}\text { Number of } \\
\text { model } \\
\text { cells } \\
\text { with an } \\
\text { optimized } \\
\text { ground- } \\
\text { water } \\
\text { withdrawal } \\
\text { rate of zero }\end{array}$ & $\begin{array}{l}\text { Ground-water } \\
\text { sustainable } \\
\text { yield, } \\
\text { (cubic feet } \\
\text { per day) }\end{array}$ & $\begin{array}{l}\text { Ground-water } \\
\text { sustainable } \\
\text { yield relative to } \\
\text { actual } 1997 \\
\text { ground-water } \\
\text { withdrawal } \\
\text { rate, } \\
\text { (percent) }\end{array}$ & $\begin{array}{l}\text { Ground-water } \\
\text { sustainable } \\
\text { yield relative } \\
\text { to ground- } \\
\text { water sustain- } \\
\text { able yield of } \\
\text { scenario 1, } \\
\text { (percent) }\end{array}$ & $\begin{array}{c}\text { Number of } \\
\text { binding } \\
\text { constraint } \\
\text { points }\end{array}$ \\
\hline 1 & 1.00 & 3,325 & $360,270,611$ & 57 & 100 & 67 \\
\hline 2 & 0.75 & 1,445 & $374,134,628$ & 59 & 104 & 37 \\
\hline 3 & 0.50 & 785 & $281,642,327$ & 44 & 78 & 15 \\
\hline 4 & 0.25 & 10 & $158,724,609$ & 25 & 44 & 2 \\
\hline
\end{tabular}

the upper ground-water withdrawal limit for each scenario. The total number of $1-\mathrm{mi}^{2}$ model cells in which an optimized ground-water withdrawal rate was calculated to be zero was $3,325,1,445,785$, and 10 for upper limits of ground-water withdrawal rates specified as $100,75,50$, and 25 percent of the 1997 ground-water withdrawal rates, respectively. In addition, the number of binding-constraint points was $67,37,15$, and 2, respectively. Distribution of ground-water sustainable yield is shown in figures 2-5. Results from scenario 4 of this analysis show that by reducing the upper limit to 25 percent of the 1997 withdrawal rate, pumping is sustainable in all but 10 model cells. The aquifer thickness specified in the model near these 10 model cells is too thin to permit a rate of withdrawal reduced to 25 percent of 1997 rates.

For the case of reducing the upper ground-water withdrawal limit to 75 percent of the 1997 rate (fig. 3), the overall ground-water withdrawal rate actually increases by $13,864,017$ $\mathrm{ft}^{3} / \mathrm{d}$ over the ground-water withdrawal rate for the baseline scenario. An explanation for this increase in ground-water sustainable yield may be through analogy with gas mileage for an automobile that can travel 30 miles per gallon of gasoline at 50 miles per hour, as opposed to being able to travel only 20 miles per gallon of gasoline at 80 miles per hour. As more stress is placed on the ground-water system, a point is reached where optimal ground-water sustainable yield declines. The relative change in ground-water sustainable yield for this scenario is shown in figure 6.

\section{White River Streamflow Constraint Analysis}

Using scenario 1 of Czarnecki (2003a) as a baseline scenario, streamflow constraints for the White River were varied to determine the maximum sustainable streamflow rate at DeValls Bluff, Arkansas (fig. 1) for comparison against average spring floods and habitat requirements for select aquatic species. The streamflow constraint value of $665,000,000 \mathrm{ft}^{3} / \mathrm{d}$ for the White River used in the baseline scenario (table 1) was supplied by the ANRC as a minimum flow rate that should be maintained throughout the year (Steve Loop, Arkansas Natural Resources Commission, written commun., 2001).

Maximum, mean, median, and minimum monthly streamflow data were compiled for the period 1989 to 2005 for data collected at the DeValls Bluff streamflow gage (table 3; fig. 7). The period 1989 to 2005 was selected because it is the period with the most continuous streamflow data following the construction of major upstream reservoirs that regulated streamflow within the White River drainage. The gage is located near a planned diversion point along the White River near DeValls Bluff that would supply water to the Grand Prairie Area Demonstration Project (fig. 1). Maximum, mean, median, and minimum annual streamflow value were compiled by averaging the 12 monthly values.

Within the optimization model, 11 rivers are specified. Surface-water diversion rates that occurred in 2000 were subtracted from specified overland flow at the appropriate river cells. Included in these diversions were the planned diversions of $63,339,248 \mathrm{ft}^{3} / \mathrm{d}$ for the Bayou Meto project area and $55,078,367 \mathrm{ft}^{3} / \mathrm{d}$ for the Grand Prairie project area.

Various combinations of river constraints along the White River model cells were specified to determine the maximum streamflow that could be maintained at DeValls Bluff. Results from the optimization model show that maximum simulated steady-state streamflow that can be sustained on an annual basis is 2,881,000,000 ft $3 / \mathrm{d}$ at DeValls Bluff. This result assumes an estimated average annual inflow of 1,248,480,000 $\mathrm{ft}^{3} / \mathrm{d}$ at the first model cell of the White River from upstream sources, and an estimated average overland flow to each of the 150 White River model cells of $12,049,751 \mathrm{ft}^{3} / \mathrm{d}$ per cell. The maximum sustainable streamflow $\left(2,881,000,000 \mathrm{ft}^{3} / \mathrm{d}\right)$ accounts for any surface withdrawals that would have occurred from surface-water diversion points in 2000 , as well as the proposed withdrawal of 55,078,367 $\mathrm{ft}^{3} / \mathrm{d}$ for the Grand Prairie 


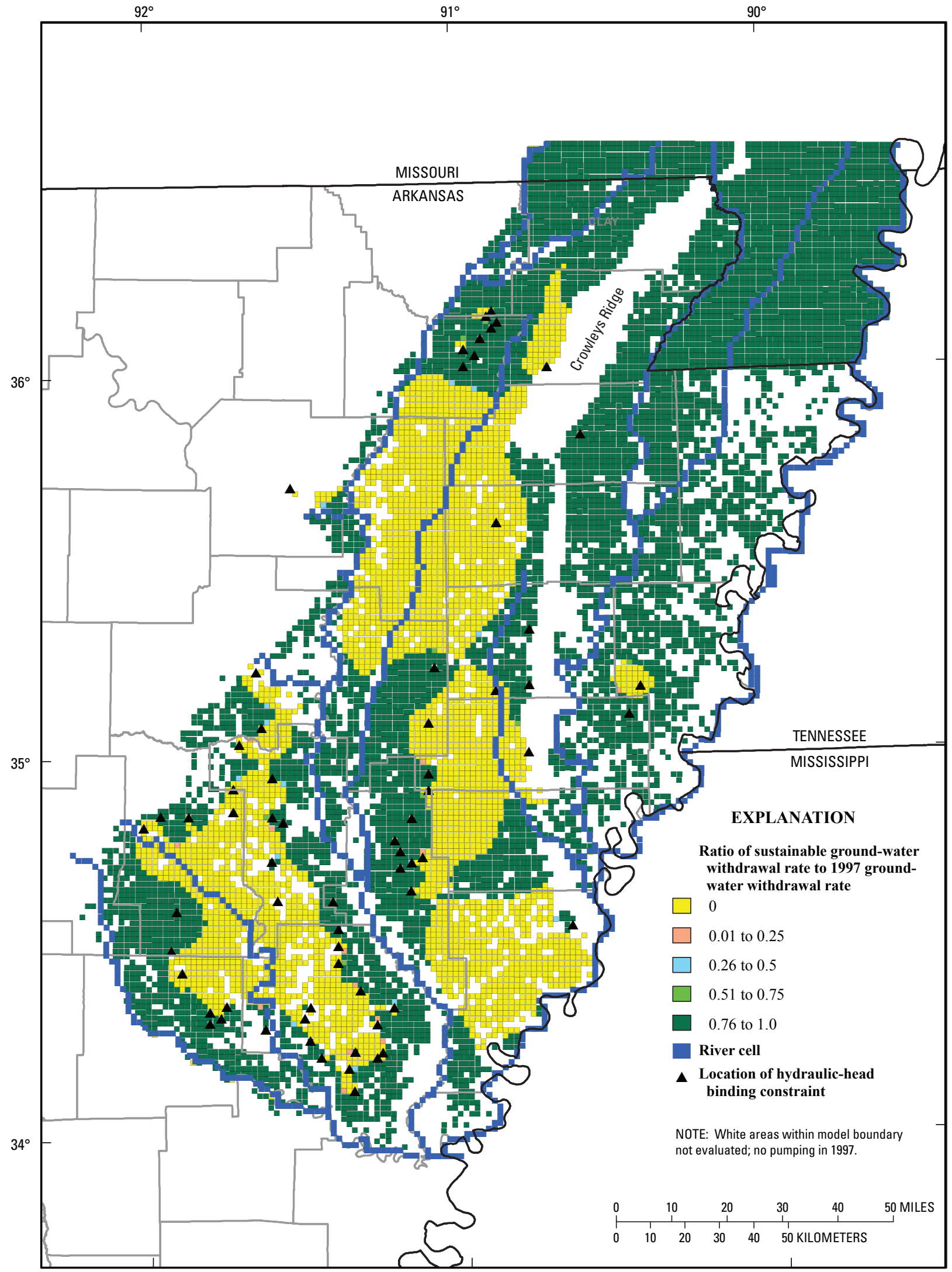

Base from U.S. Census Tiger/line files, 2003

Figure 2. Optimized ground-water withdrawal rates and binding-constraint locations for scenario 1 (baseline), maximum withdrawal ratio of 1.0 . 


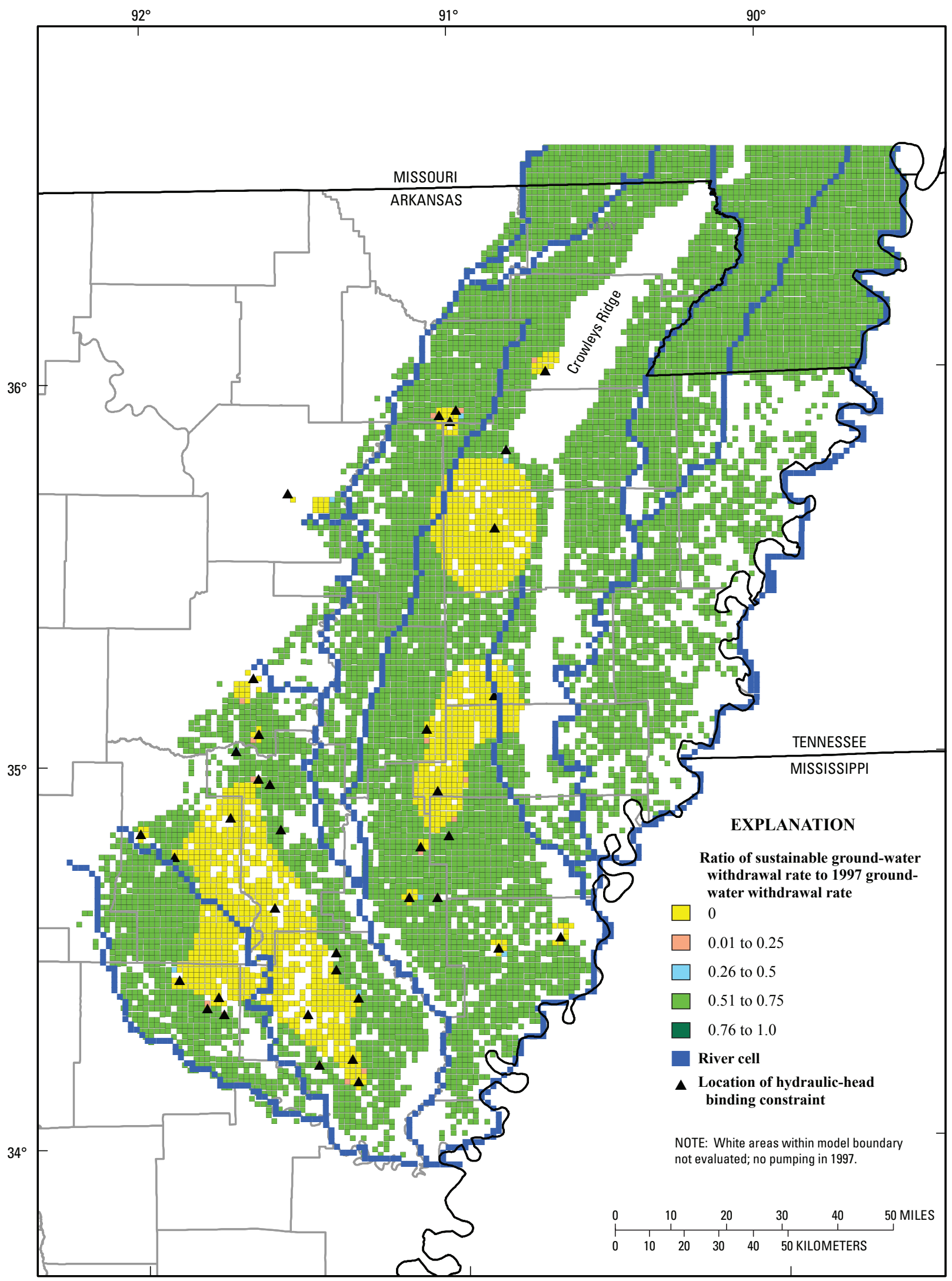

Base from U.S. Census Tiger/line files, 2003

Figure 3. Optimized ground-water withdrawal rates and binding-constraint locations for scenario 2, maximum withdrawal ratio of 0.75 . 


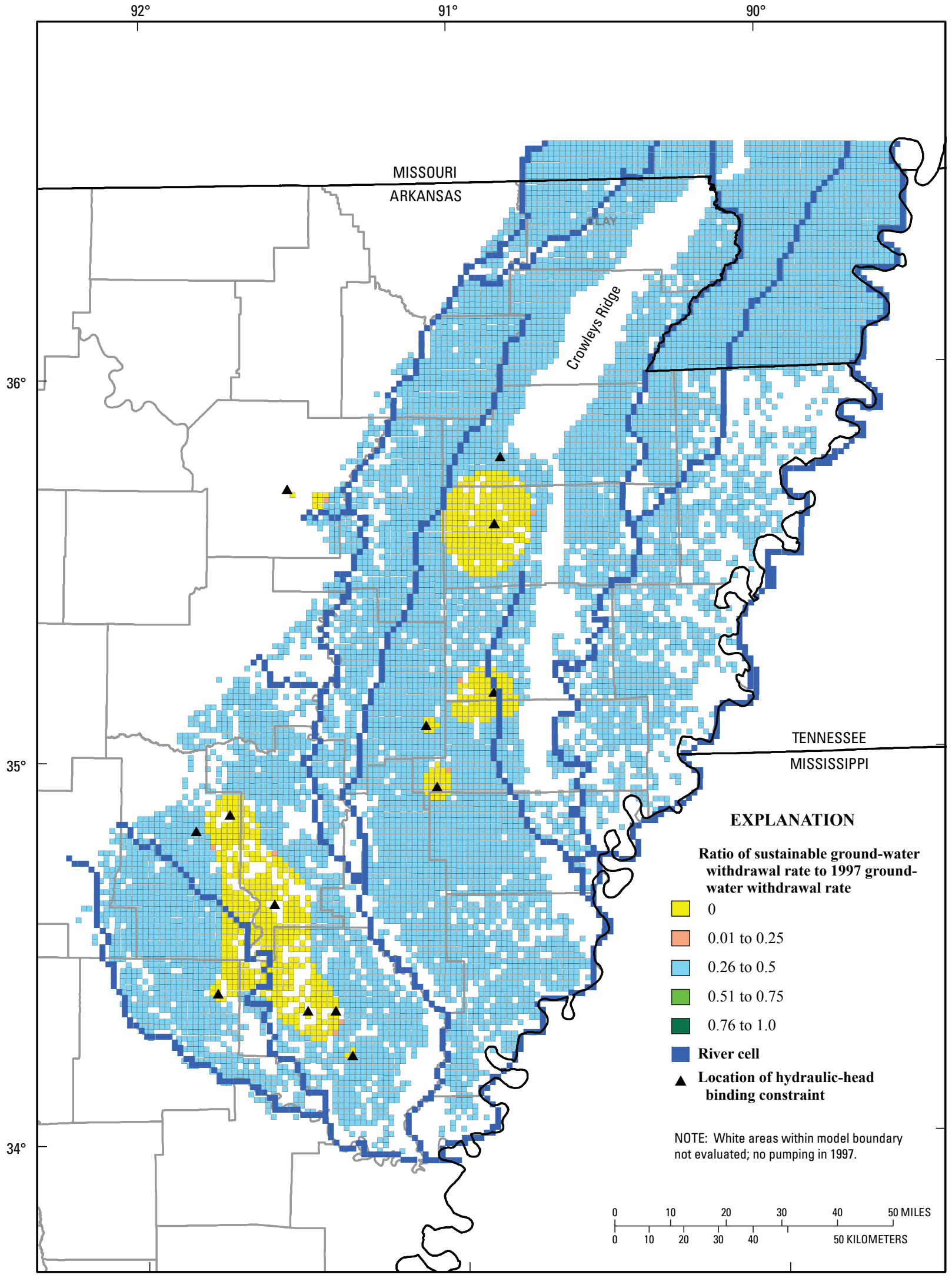

Base from U.S. Census Tiger/line files, 2003

Figure 4. Optimized ground-water withdrawal rates and binding-constraint locations for scenario 3 , maximum withdrawal ratio of 0.50 . 


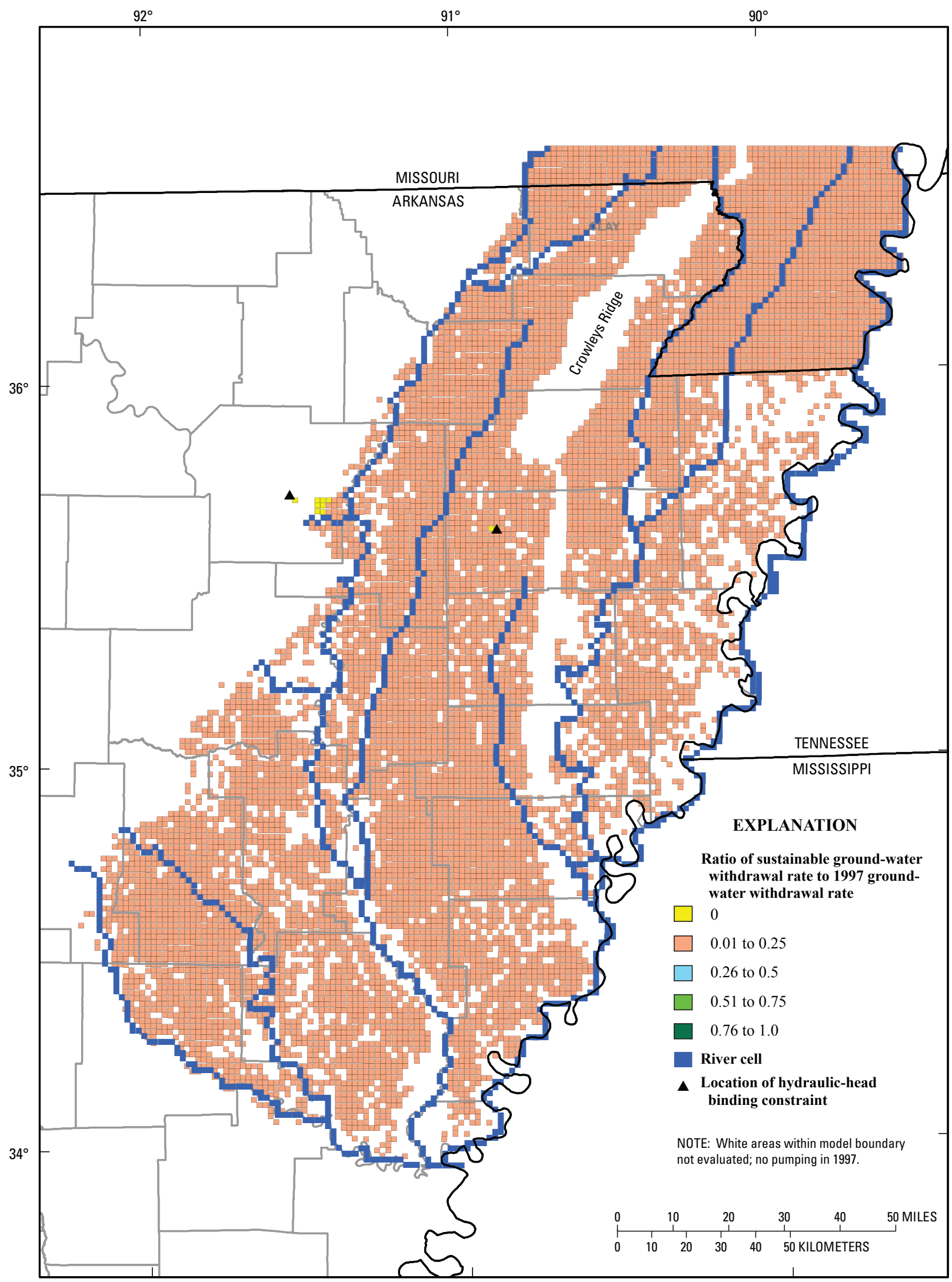

Base from U.S. Census Tiger/line files, 2003

Figure 5. Optimized ground-water withdrawal rates and binding-constraint locations for scenario 4, maximum withdrawal ratio of 0.25. 


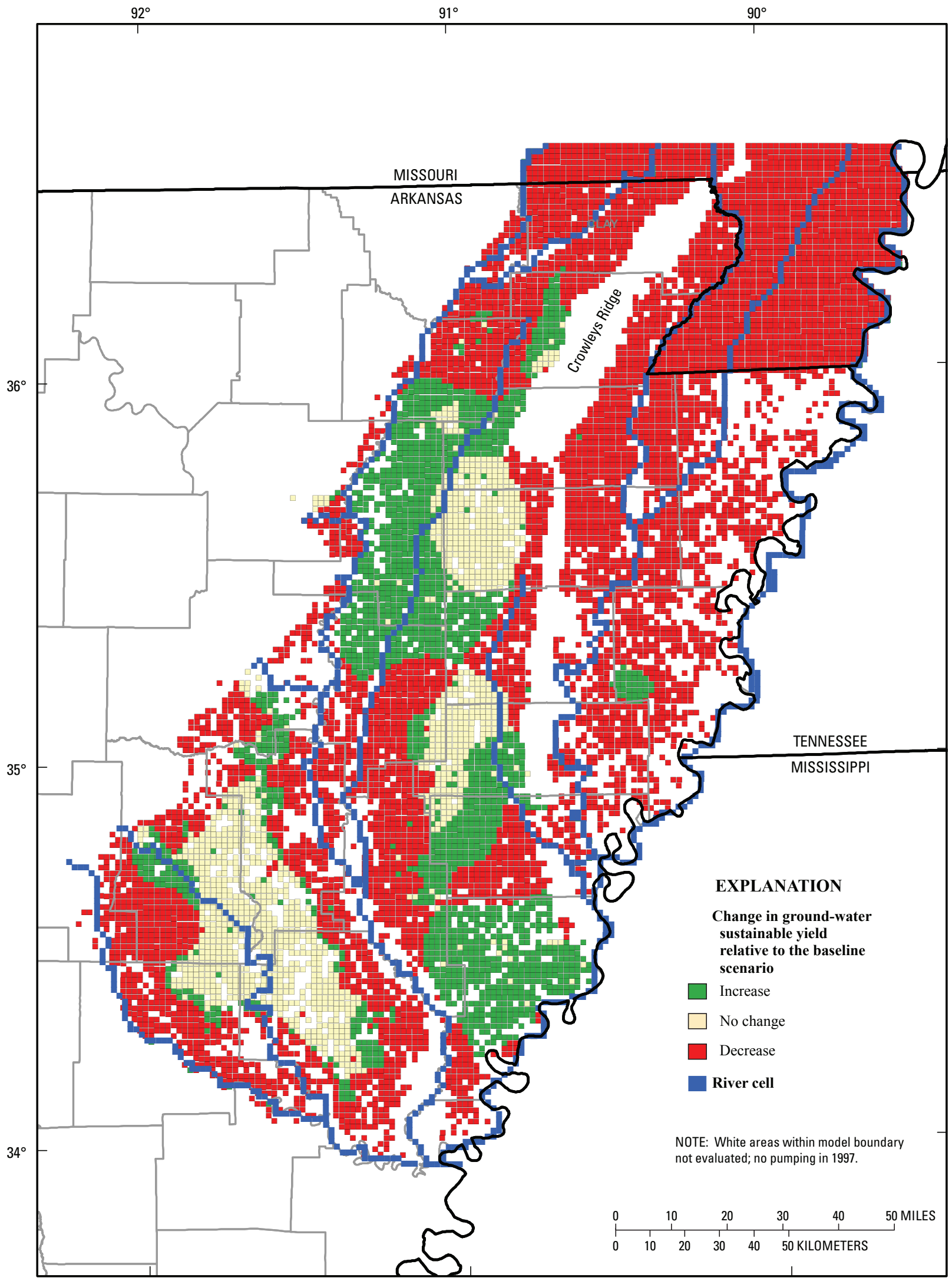

Base from U.S. Census Tiger/line files, 2003

Figure 6. Change in ground-water withdrawal sustainable yield relative to the baseline scenario 1 compared to a maximum withdrawal ratio of 0.75 in scenario 2 . 
Table 3. Monthly and annual streamflow statistics for U.S. Geological Survey streamflow gaging station 07077000 , White River at DeValls Bluff, Arkansas, 1989 to 2005.

[All streamflow values in cubic feet per day from http://waterdata.usgs.gov/ar/nwis/monthly]

\begin{tabular}{lrrrr}
\hline \multicolumn{1}{c}{ Month } & Mean & Median & Maximum & Minimum \\
\hline January & $2,666,481,600$ & $2,483,136,000$ & $6,045,408,000$ & $559,958,400$ \\
February & $3,284,775,529$ & $3,380,832,000$ & $6,994,080,000$ & $1,119,744,000$ \\
March & $3,461,424,000$ & $3,153,168,000$ & $6,312,384,000$ & $1,143,936,000$ \\
April & $3,434,352,000$ & $3,891,456,000$ & $5,952,960,000$ & $1,166,400,000$ \\
May & $3,004,310,400$ & $2,925,936,000$ & $5,050,080,000$ & $643,507,200$ \\
June & $2,132,956,800$ & $2,094,336,000$ & $3,556,224,000$ & $576,806,400$ \\
July & $1,749,376,376$ & $1,749,600,000$ & $2,707,776,000$ & $756,518,400$ \\
August & $1,420,060,235$ & $1,270,944,000$ & $2,388,096,000$ & $908,064,000$ \\
September & $1,126,508,612$ & $1,080,000,000$ & $2,138,400,000$ & $726,969,600$ \\
October & $1,019,128,659$ & $914,976,000$ & $2,179,008,000$ & $497,664,000$ \\
November & $1,436,633,788$ & $967,680,000$ & $3,245,184,000$ & $505,872,000$ \\
December $_{\text {Annual }}{ }^{-}$ & $2,442,919,341$ & $2,073,600,000$ & $5,772,384,000$ & $537,926,400$ \\
\hline
\end{tabular}

${ }^{1}$ Annual values were computed by averaging the 12 monthly values.

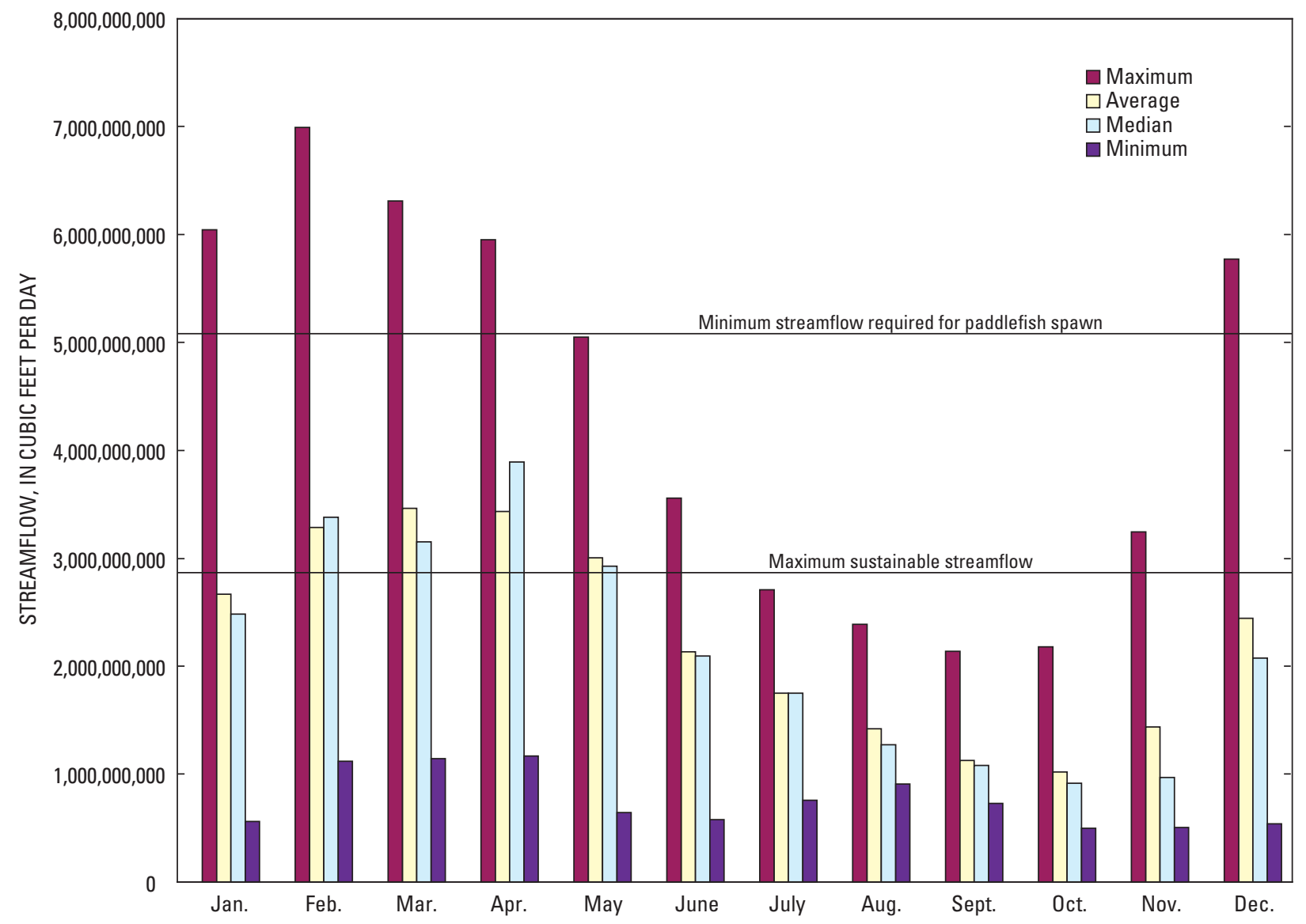

Figure 7. Monthly average maximum, mean, median, and minimum streamflow from 1989 to 2005 at DeValls Bluff gage on the White River. 
project area. Table 4 summarizes the simulated streamflow components at DeValls Bluff.

Table 4. Summary of simulated streamflow components for the White River model cell at DeValls Bluff, Arkansas.

\begin{tabular}{lr}
\hline \multicolumn{1}{c}{ Streamflow component } & $\begin{array}{c}\text { Flow rate } \\
\text { (cubic feet per day) }\end{array}$ \\
\hline $\begin{array}{l}\text { Average annual inflow at first model } \\
\text { cell of the White River }\end{array}$ & $1,248,480,000$ \\
Average annual overland flow to White & $1,369,772,764$ \\
$\quad$ River upstream from DeValls Bluff & \\
Average overland flow to each of the & $12,049,751$ \\
150 White River model cells & \\
Total streamflow at DeValls Bluff \\
$\quad$ (overland flow plus specified inflow \\
into first model cell) \\
$\begin{array}{l}\text { Maximum sustainable yield from } \\
\text { White River at DeValls Bluff }\end{array}$ \\
$\begin{array}{l}\text { Amount of streamflow contributed by } \\
\text { ground water }\end{array}$
\end{tabular}

The maximum sustainable streamflow of 2,881,000,000 $\mathrm{ft}^{3} / \mathrm{d}$ at DeValls Bluff that was calculated using the optimization model can be thought of as an average annual flow rate maintained indefinitely, because the optimization model assumes steady-state flow conditions. Streamflow in the White River varies seasonally, as shown in table 3 and figure 7. The maximum sustainable streamflow of $2,881,000,000$ $\mathrm{ft}^{3} / \mathrm{d}$ exceeds the average mean annual streamflow and median annual streamflow for the period 1989 to 2005 by $616,089,388$ $\mathrm{ft}^{3} / \mathrm{d}$ and 715,528,000 ft $\mathrm{ft}^{3} / \mathrm{d}$, respectively. Mean and median monthly streamflow exceeds the maximum sustainable streamflow for the months of February through May. The component of ground-water flow to the White River is 262,747,236 $\mathrm{ft}^{3} / \mathrm{d}$. In contrast, the sustainable yield from ground water for the entire model area is $359,453,721 \mathrm{ft}^{3} / \mathrm{d}$ for the White River streamflow constraint scenario compared to $360,270,611 \mathrm{ft}^{3} / \mathrm{d}$ for the baseline scenario.

As stated earlier, streamflow constraints may be specified based on streamflow required for various fish habitats. Paddlefish require the most streamflow for spawning of any fish species in the White River. During the paddlefish spawn which occurs in the spring, a streamflow rate of 5,097,600,000 $\mathrm{ft}^{3} / \mathrm{d}$ is allocated (Steve Loop, Arkansas Natural Resources Commission, written commun., 2007). Because the optimization model specifies steady-state conditions, seasonal variations in sustainable streamflow were not calculated. A review of table 3 and figure 7 shows that no mean or median monthly streamflows are large enough to provide sufficient streamflow to meet this requirement. Only maximum monthly streamflows for December through April are large enough to meet this requirement. Streamflow needed to support the paddlefish spawn may not be sufficient in all years because of natural variability in streamflow. The maximum sustainable streamflow at DeValls Bluff on the White River was calculated as $2,881,000,000 \mathrm{ft}^{3} / \mathrm{d}$, which is larger than the mean and median annual streamflow values shown in table 3 .

\section{Specified White River Stage}

Near the confluence of the White River and the Mississippi River, the White River and Arkansas River are separated by flood-control structures to keep the White River from flowing into the Arkansas River. During flood events, the Melinda Head Cut Structure (one of these flood-control structures) is designed to act as a spillway (figs. 8-10); however, if not maintained, the likelihood of complete failure of this structure is great. If no maintenance is performed, the probability of failure within a 5-year period is estimated to be 75 percent (Trisha Anslow, U.S. Corps of Engineers, oral commun., 2004).

If the Melinda Head Cut Structure were to fail completely, allowing the White River to flow into the Arkansas River, a new, lower base level for the White River would result, causing an increase in gradient in the White River, which would result in higher energy streamflows, increased streambed scouring, and a reduction in the stage of the White River. For the current analyses, the gradient of the White River is assumed to be reduced uniformly and completely up to the first control structure at Newport, Arkansas (fig. 1); however, the ultimate scouring of the streambed might not terminate for decades. To assess the effect of a hypothetical failure of the Melinda Head Cut Structure on the sustainable yield of ground water from the alluvial aquifer, the specified river stage of the White River assigned to each model cell was reduced in the model of Czarnecki and others (2003a). Because of the uncertainty as to how much lowering might occur on an annual average, a range of values was used. As river stage is reduced, the amount of water recharged from the White River to the alluvial aquifer decreases.

River stage was reduced linearly over the 150 river cells of the White River in the model, assuming a reduction of 20 , 30 , and $40 \mathrm{ft}$ at the most downstream river cell of the White River near its hypothetical confluence with the Arkansas River and no change in the uppermost river cell. The selection of these values was based on a visual estimation of the stage difference between the White River and the Arkansas River during a site visit on March 29, 2006. The resulting changes in ground-water sustainable yields are shown in table 5 and figure 11. Ground-water sustainable yield decreased by $6,892,574 \mathrm{ft}^{3} / \mathrm{d}, 10,862,026 \mathrm{ft}^{3} / \mathrm{d}$, and $13,731,969 \mathrm{ft}^{3} / \mathrm{d}$, respectively.

As river stage decreases, so does ground-water sustainable yield from the entire model area. However, decreases do not occur everywhere in the model area. Spatial changes in sustainable yield at individual model cells for each of these scenarios are shown in figures 12-14. 


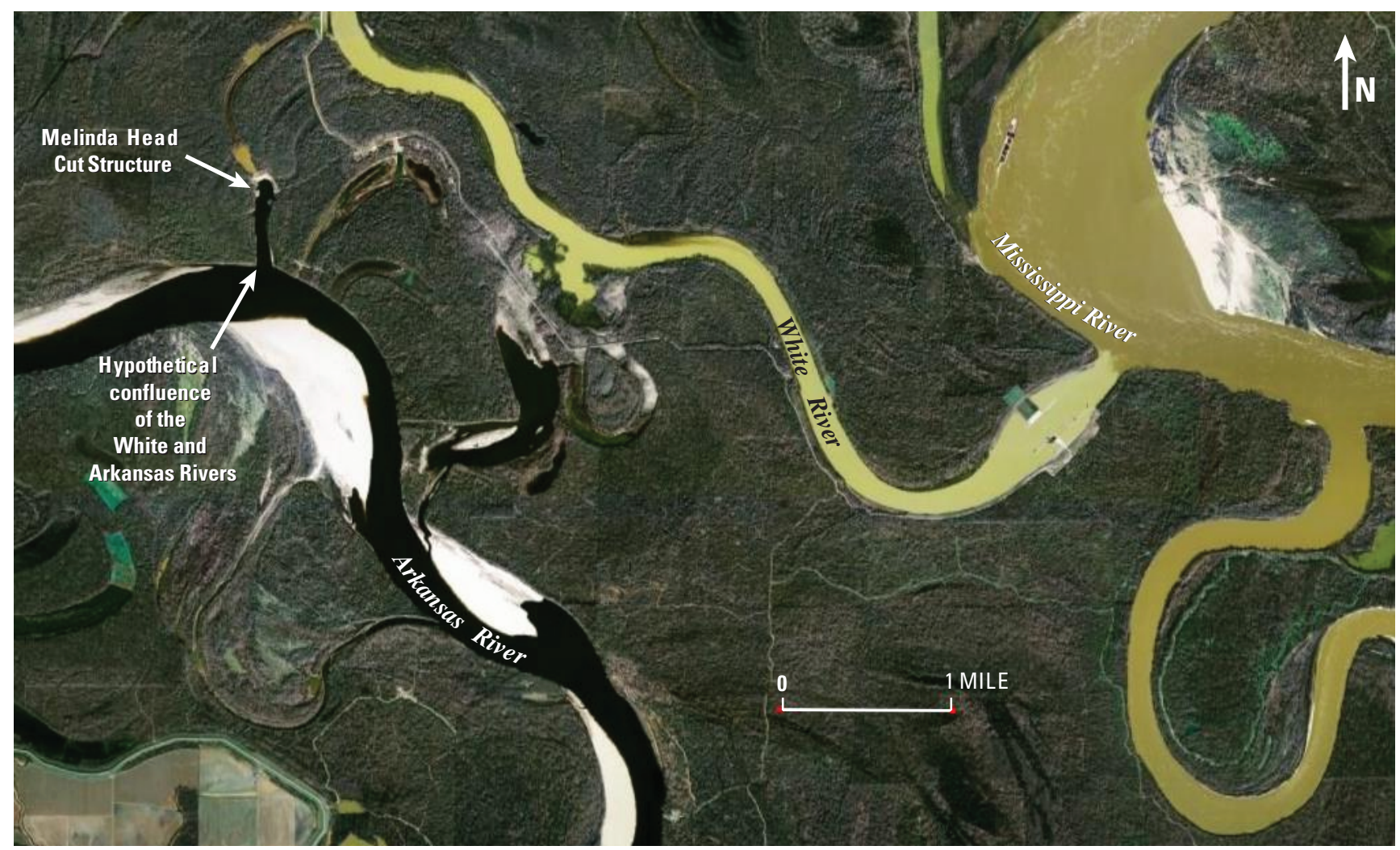

Base from Google earth, 2007

Figure 8. Areal view of Melinda Head Cut Structure relative to the White, Arkansas, and Mississippi Rivers. Image accessed from Google Earth, August 13, 2007, at URL http://earth/google.com/ 


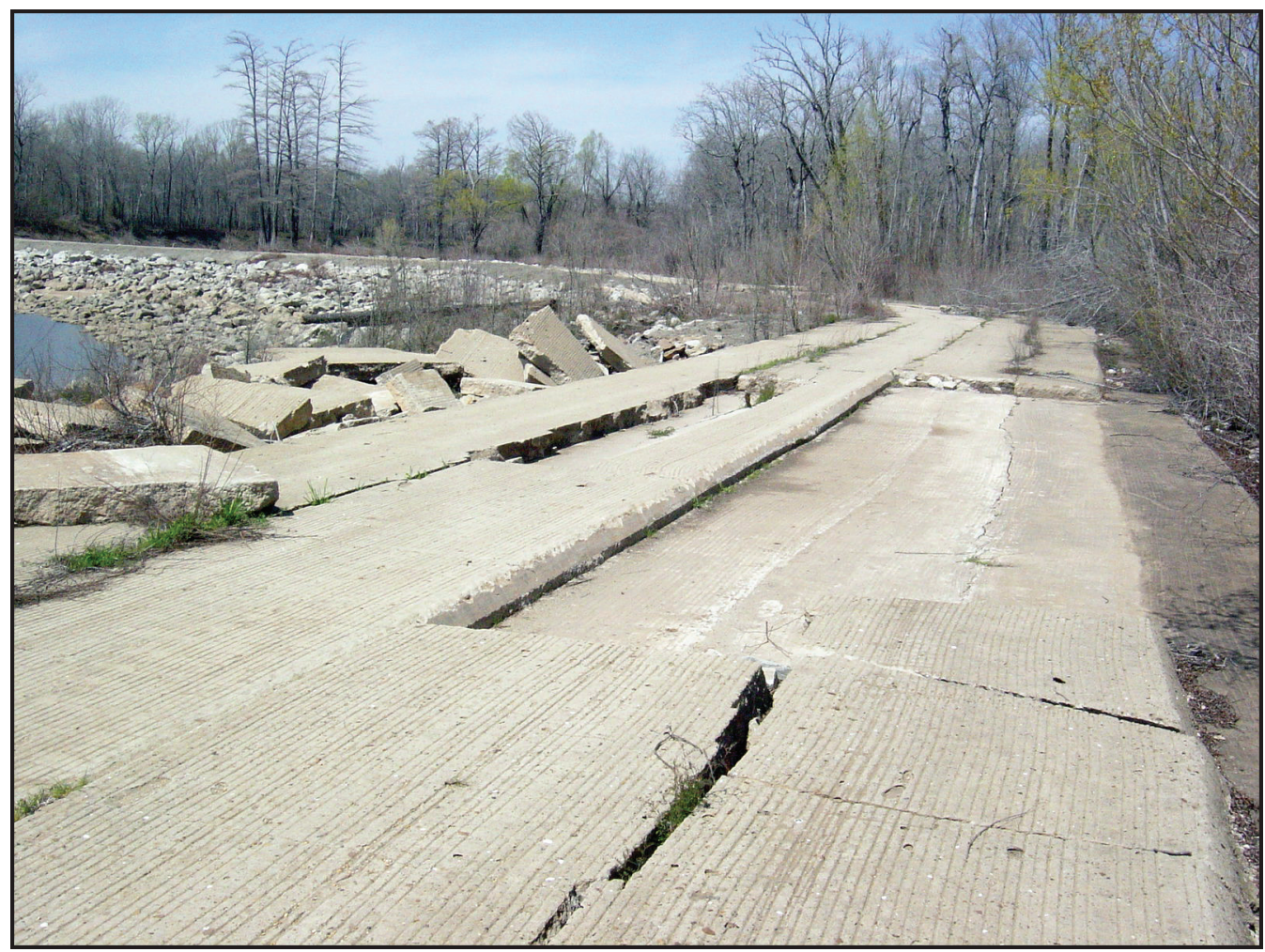

Figure 9. Melinda Head Cut Structure looking toward the northwest. Concrete slabs located toward the water were transported by flood water from the White River. Photograph by John B. Czarnecki, U.S. Geological Survey.

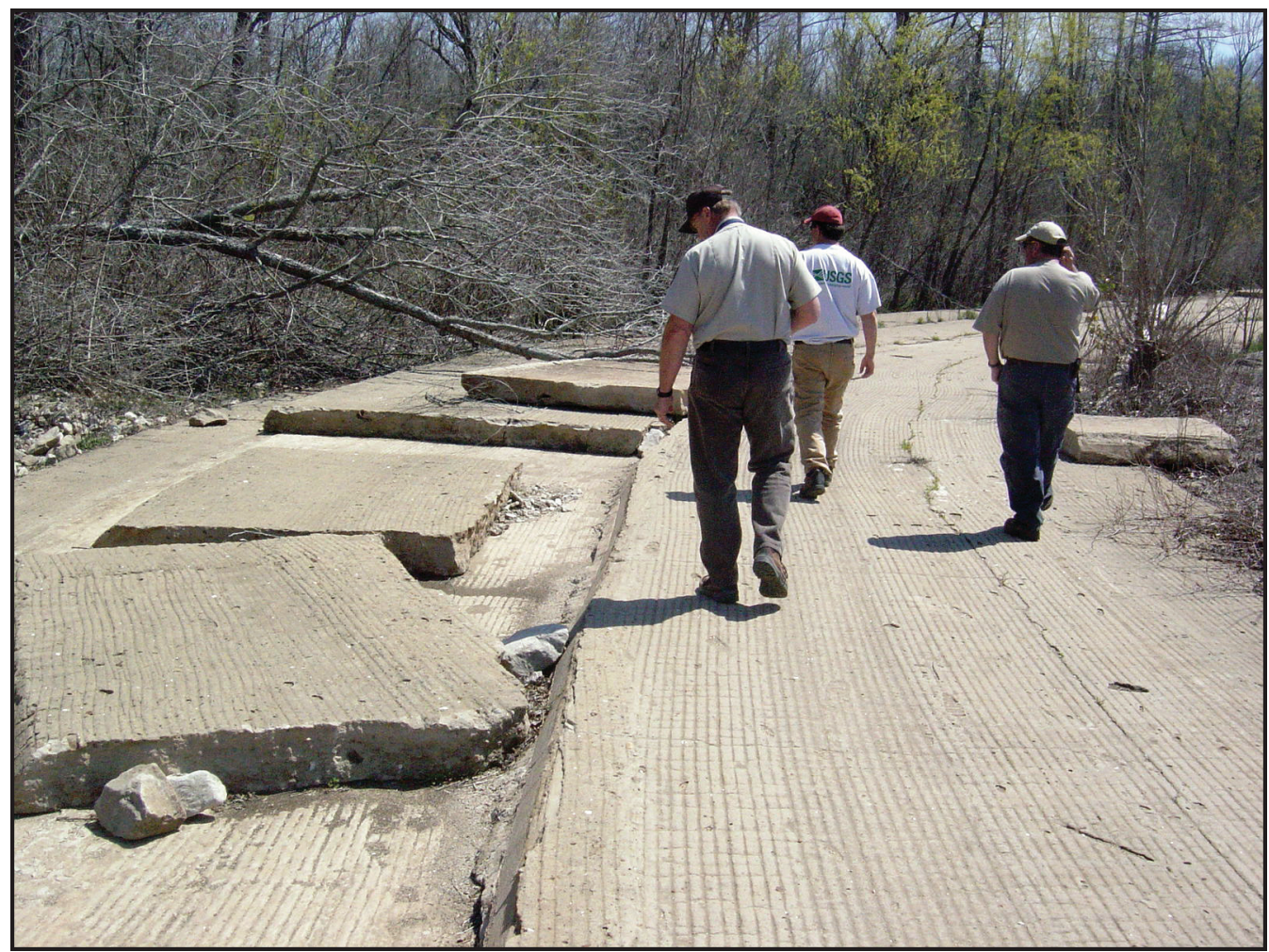

Figure 10. Damage along the top of the Melinda Head Cut Structure, spring 2005. Concrete slabs weremoved by the force of flood waters from the White River, which covered the Melinda Head Cut Structure. Photograph by John B. Czarnecki, U.S. Geological Survey. 
Table 5. Effect of lowering White River stage on ground-water sustainable yield of the alluvial aquifer.

\begin{tabular}{ccc}
\hline $\begin{array}{c}\text { Decrease in White River } \\
\text { stage near its hypothe- } \\
\text { tical confluence with } \\
\text { the Arkansas River } \\
\text { (feet) }\end{array}$ & $\begin{array}{c}\text { Ground-water } \\
\text { sustainable } \\
\text { yield } \\
\text { (cubic feet } \\
\text { per day) }\end{array}$ & $\begin{array}{c}\text { Decrease in ground-water } \\
\text { sustainable yield from } \\
\text { baseline scenario value } \\
\text { of sustainable yield } \\
\text { (cubic feet per day) }\end{array}$ \\
\hline 0 (baseline) & $360,270,611$ & 0 \\
20 & $353,378,037$ & $6,892,574$ \\
30 & $349,408,585$ & $10,862,026$ \\
40 & $346,538,642$ & $13,731,969$ \\
\hline
\end{tabular}

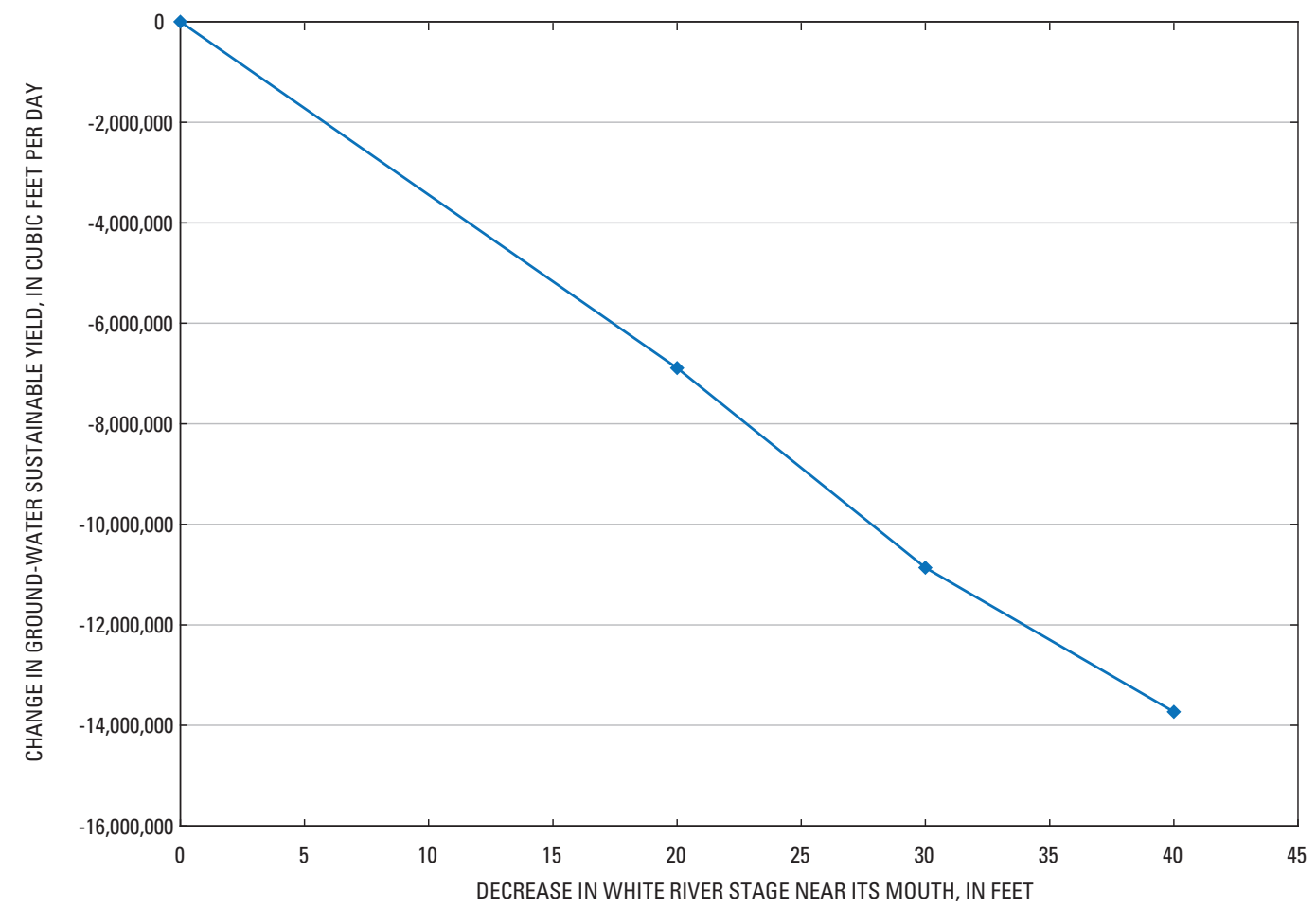

Figure 11. Change in ground-water sustainable yield of the alluvial aquifer with stage of White River. 


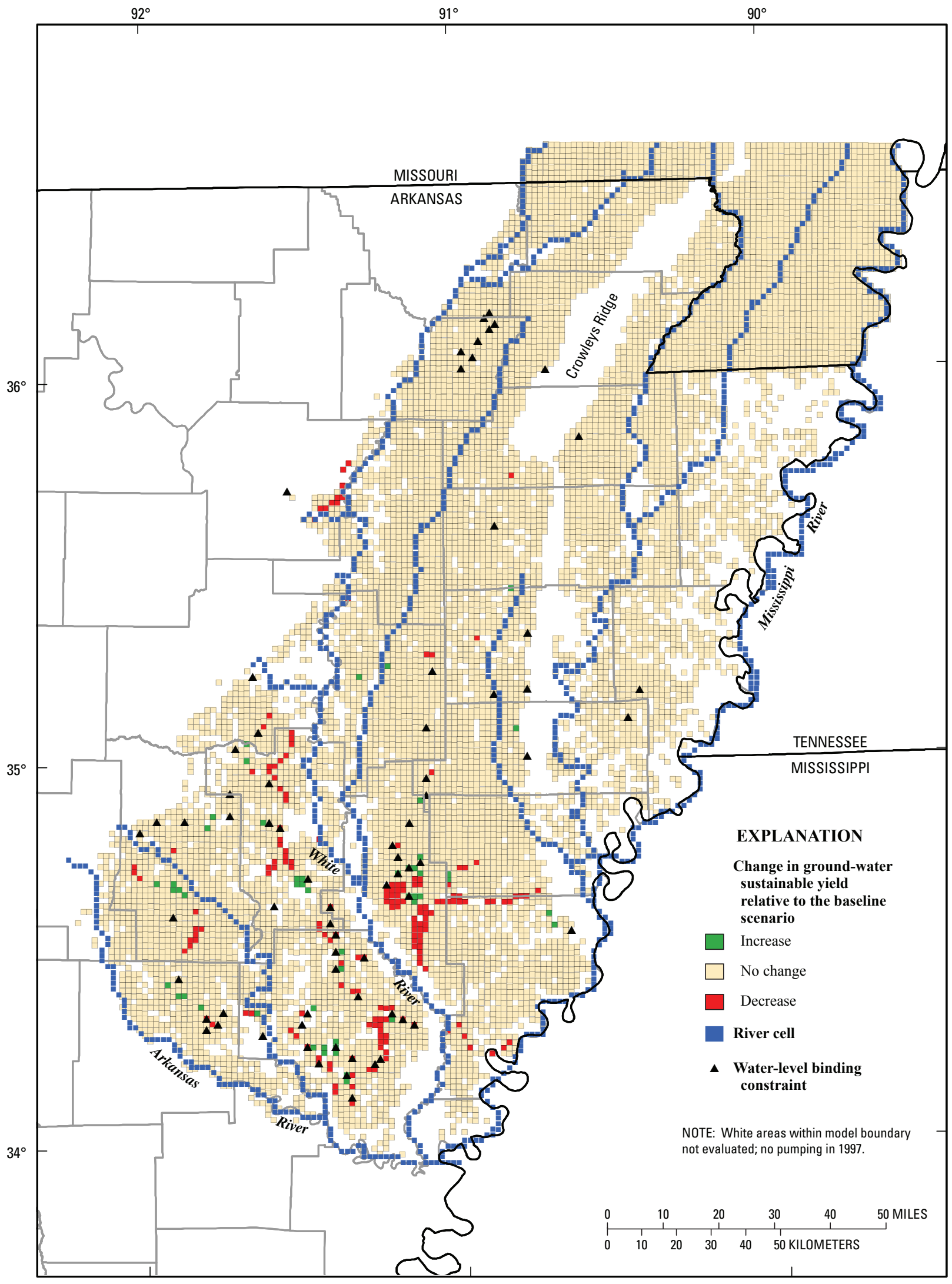

Base from U.S. Census Tiger/line files, 2003

Figure 12. Change in ground-water sustainable yield relative to the baseline scenario for a decline in the stage of the White River by 20 feet near its hypothetical confluence with the Arkansas River. 


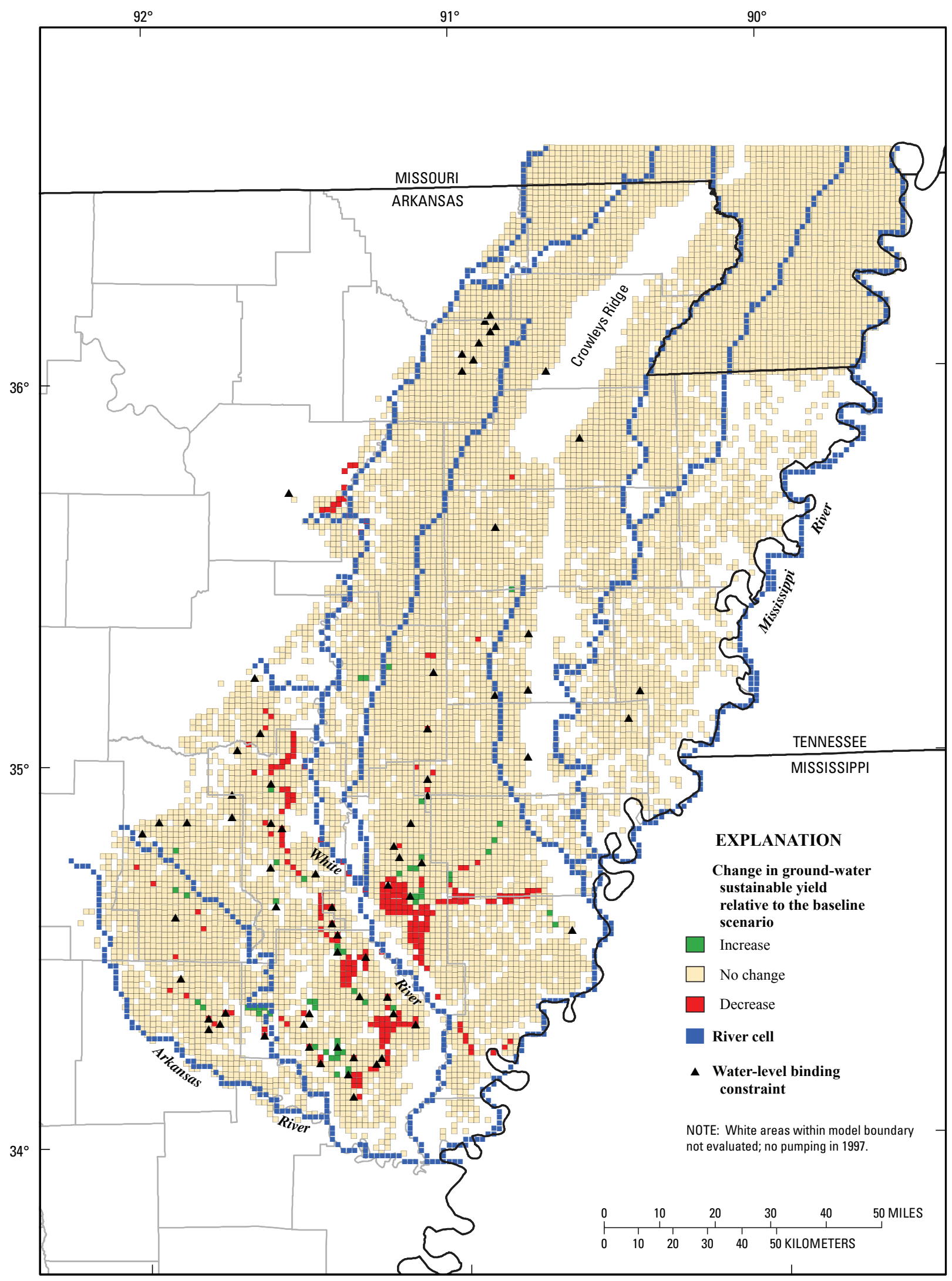

Base from U.S. Census Tiger/line files, 2003

Figure 13. Change in ground-water sustainable yield relative to the baseline scenario for a decline in the stage of the White River by 30 feet near its hypothetical confluence with the Arkansas River. 


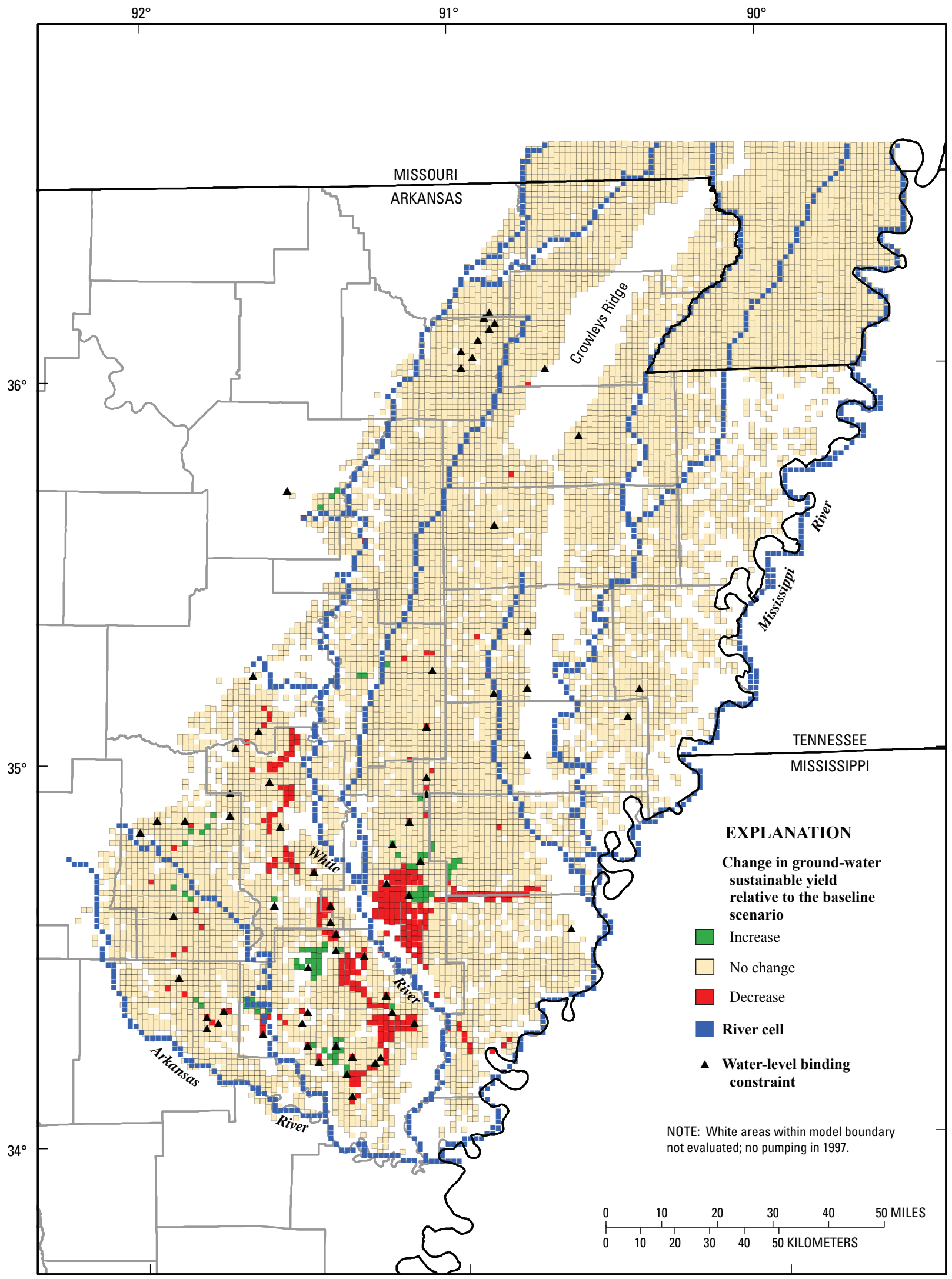

Base from U.S. Census Tiger/line files, 2003

Figure 14. Change in ground-water sustainable yield relative to the baseline scenario for a decline in the stage of the White River by 40 feet near its hypothetical confluence with the Arkansas River. 


\section{Summary and Conclusions}

A conjunctive-use optimization model of the Mississippi River Valley alluvial aquifer was used to evaluate the effect of water-level altitude and streamflow constraints and model variables (maximum allowable pumping rates at wells and river stage) on ground-water sustainable yield. Modifications to the optimization model were made to evaluate the effects of varying (1) the upper limit of ground-water withdrawal rates, (2) the streamflow-constraint values for the White River representing minimum specified flow rates corresponding to either the average spring flood or habitat requirements for select aquatic species, and (3) the specified stage of the White River as it might apply to the formation of a hypothetical confluence of the White and Arkansas Rivers. Upper limit of groundwater withdrawal rates were reduced to 75,50 , and 25 percent of the 1997 ground-water withdrawal rates. As the upper limit is reduced, the distribution of sustainable pumping increases, and the number of binding constraints decreases, because water-level altitudes are not lowered as much when maximum pumping rates are reduced. The total number of $1-\mathrm{mi}^{2}$ model cells in which an optimized ground-water withdrawal rate was calculated to be zero was $3,325,1,445,785$, and 10 for upper limits of ground-water withdrawal rates specified as 100, 75, 50, and 25 percent of the 1997 ground-water withdrawal rates, respectively. In addition, the number of binding-constraint points was $67,37,15$, and 2, respectively. For an upper limit for the ground-water withdrawal rate set at 75 percent of the 1997 withdrawal rate, ground-water sustainable yield for the entire model area increased by $13,864,017 \mathrm{ft}^{3} / \mathrm{d}$ over the baseline scenario.

Varying the streamflow constraint associated with the

White River resulted in an optimized maximum simulated sustainable streamflow of 2,881,000,000 $\mathrm{ft}^{3} / \mathrm{d}$ for the White River at DeValls Bluff, Arkansas, the site of potential surface-water withdrawals from the White River for the Grand Prairie Area Demonstration Project. The planned diversion rate for the Grand Prairie Area Demonstration Project is 55,078,367 ft $\mathrm{ft}^{3} / \mathrm{d}$. Ground-water sustainable yield for the entire model area using this streamflow constraint was $359,453,721 \mathrm{ft}^{3} / \mathrm{d}$ compared to a value of $360,270,611 \mathrm{ft}^{3} / \mathrm{d}$ for the baseline scenario. During the paddlefish spawn which occurs in the spring, a streamflow rate of $5,097,600,000 \mathrm{ft}^{3} / \mathrm{d}$ is allocated. Because the optimization model specifies steady-state conditions, seasonal variations in sustainable streamflow were not calculated.

Decreasing the specified stage of the White River was done to evaluate a hypothetical river stage that might result if the White River were to breach the Melinda Head Cut Structure, one of several flood-control structures that prevent the White River from permanently flowing into the Arkansas River. Declines in the stage of the White River cause declines in the sustainable yield of ground water. For changes in stage near the hypothetical confluence of the White and Arkansas Rivers of 20,30, and $40 \mathrm{ft}$, ground-water sustainable yield decreased by $6,892,574 \mathrm{ft}^{3} / \mathrm{d}, 10,862,026 \mathrm{ft}^{3} / \mathrm{d}$, and $13,731,969$ $\mathrm{ft}^{3} / \mathrm{d}$, respectively.

The application of conjunctive-use optimization modeling discussed in this report provides important information to water managers concerned about ground-water sustainable yield of the alluvial aquifer and its relation to streamflow. The analyses presented herein emphasize the fact that there is no single value of sustainable yield from either ground water or surface water, but is a value dependent on constraints imposed within the model. 


\section{References}

Ahlfeld, D.P. and Mulligan, A.E., 2000, Optimal management of flow in groundwater systems: New York, Academic Press, $185 \mathrm{p}$.

Czarnecki, J.B., Clark, B.R., and Reed, T.B., 2003a, Conjunctive-use optimization model of the Mississippi River Valley alluvial aquifer of northeastern Arkansas: U.S. Geological Survey Water-Resources Investigations Report 03-4230, 29 p.

Czarnecki, J.B., Clark, B.R., and Stanton, G.P., 2003b, Conjunctive-use optimization model of the Mississippi River Valley alluvial aquifer of southeastern Arkansas: U.S. Geological Survey Water-Resources Investigations Report 03-4233, $26 \mathrm{p}$.

Czarnecki, J.B., 2006, Simulation of Various Management Scenarios of the Mississippi River Valley Alluvial Aquifer in Arkansas: U.S. Geological Survey Scientific Investigations Report 2006-5052, 21 p.

Greenwald, R.M., 1998, Documentation and user's guide: MODMAN, An optimization module for MODFLOW version 4.0: Freehold, New Jersey, HSI GeoTrans, 112 p.

Reed, T.B., 2003, Recalibration of a ground-water flow model of the Mississippi River Valley alluvial aquifer of northeastern Arkansas, 1918-1998, with simulations of water levels caused by projected ground-water withdrawals through 2049: U.S. Geological Survey Water-Resources Investigations Report 03-4109, 58 p.

Schrader, T.P., 2001, Status of water levels and selected waterquality conditions in the Mississippi River Valley alluvial aquifer in eastern Arkansas, 2000: U.S. Geological Survey Water-Resources Investigations Report 01-4124, 52 p.

Stanton, G.P., and Clark, B.R., 2003, Recalibration of a ground-water flow model of the Mississippi River Valley alluvial aquifer in southeastern Arkansas, 1918-1998, with simulations of hydraulic heads caused by projected groundwater withdrawals through 2049: U.S. Geological Survey Water-Resources Investigations Report 03-4232, 48 p.

U.S. Army Corps of Engineers, 2006a, Grand Prairie Area Demonstration Project, accessed on January 26, 2006 at URL http://www.mvm.usace.army.mil/grandprairie/

U.S. Army Corps of Engineers, 2006b, Bayou Meto Basin Project, accessed on January 26, 2006 at URL http://www. mvm.usace.army.mil/bayoumeto/home.htm 
Publishing support provided by:

Lafayette and Rolla Publishing Service Centers

For more information concerning the research described in the report:

U.S. Geological Survey

Arkansas Water Science Center

401 Hardin Road

Little Rock, AR 72211-3528

(501) 228-3600

http://ar.water.usgs.gov 
